Trauma Surgery \& Acute Care Open

\title{
History and significance of the trauma resuscitation flow sheet
}

\author{
Julie A Dunn, ${ }^{1}$ Thomas I Schroeppel, ${ }^{2}$ Michael Metzler, ${ }^{1}$ Chris Cribari, ${ }^{1,2}$ \\ Katherine Corey, ${ }^{1}$ David R Boyd ${ }^{3}$
}

\begin{abstract}
- Additional material is published online only. To view please visit the journal online (http://dx.doi.org/10.1136/ tsaco-2017-000145).

${ }^{1}$ Trauma and Acute Care Surgery, UC Health Medical Center of the Rockies, Loveland, Colorado, USA

${ }^{2}$ Trauma and Acute Care Surgery, UC Health Memorial Hospital, Colorado Springs, Colorado, USA

${ }^{3}$ Retired, New Market, Maryland, USA
\end{abstract}

Correspondence to Dr Thomas J Schroeppel, Trauma and Acute Care Surgery, University of Colorado Health - South, Colorado Springs 80909, Colorado, USA; thomas. schroeppel@uchealth.org

Received 9 November 2017 Revised 25 July 2018 Accepted 8 August 2018

\section{ABSTRACT}

There is little to no written information in the literature regarding the origin of the trauma flow sheet. This vital document allows programs to evaluate initial processes of trauma care. This information populates the trauma registry and is reviewed in nearly every Trauma Process Improvement and Patient Safety conference when discerning the course of patient care. It is so vital, a scribe is assigned to complete this documentation task for all trauma resuscitations, and there are continual process improvement efforts in trauma centers across the nation to ensure complete and accurate data collection. Indeed, it is the single most important document reviewed by the verification committee when evaluating processes of care at site visits. Trauma surgeons often overlook its importance during resuscitation, as recording remains the domain of the trauma scribe. Yet it is the first document scrutinized when the outcome is less than what is expected. The development of the flow sheet is not a result of any consensus statement, expert work group, or mandate, but a result of organic evolution due to the need for relevant and better data. The purpose of this review is to outline the origin, importance, and critical utility of the trauma flow sheet.

\begin{abstract}
...there is a great waste of life; ... In attempting to arrive at the truth, I [have not] been able to find hospital records fit for any purpose of comparison. If they could be obtained, they would enable us to decide many questions ... these improved statistics would tell us more of the value of particular operations and modes of treatment than we have any means of obtaining at present... [T]ruth thus ascertained would enable us to save life and suffering, and to improve the treatment and management of the sick ... Florence Nightingale ${ }^{1}$
\end{abstract}

This prescient statement was made 150 years ago, yet until the 1950s charting remained negligible when Harriet Werley ${ }^{2}$ compiled a minimum set of standardized nursing data for all patients. In 1966, the National Academy of Sciences-National Research Council published Accidental Death and Disability: The Neglected Disease of Modern Society, 3 ushering in modern trauma care and the first civilian trauma units in the USA.

Very few in our population can be considered immune to a possible major traumatic injury. The satisfactory outcome of such an injury depends upon the quality of medical care and the time interval in which it is provided. At present there is no unified plan available ... for the distribution and intensive management of the critically injured. This is in part due to the lack of "hard core" information about the problem. One partial solution to this major health problem may be the development of a trauma registry. ${ }^{4}$

Given this data deficit, a fledgling trauma registry was created at the Cook County Trauma Unit. Almost immediately impediments were encountered:

I was anxious to mine the gold field of clinical material on the TU (Trauma Unit). I quickly found my first set of obstacles: (1) the Cook County Hospital patient record, (2) the Cook County Hospital record room, and (3) the inconsistent and inadequate chart recording of the period.

To have a functional trauma registry, with "hard core information," vital data were required. The solution: paper data sheets taped to the Trauma Unit walls at Cook County (Dr D Boyd, personal communication, 2016). Data included demographics, time from injury to initial care, mechanisms, injury patterns, interventions, response to therapies, transfer times, and outcomes. From the outset, charting was quickly assumed by the nursing personnel. Until that time, the quality and intensity of trauma care for civilians had never been defined. ${ }^{6}$ Data input into rapidly advancing computer systems allowed precise outputs and ability to identify high-risk highway locations, work injuries, environmental injury patterns and vital information for trauma center development, health manpower needs, cost-effectiveness, processes of care, cost analyses, and effectiveness of prehospital systems.

This environment was the birthplace and testing ground for the trauma resuscitation flow sheet. As trauma centers and systems matured, the flow sheet began to take form. Although the origins can be traced to the Trauma Unit at Cook County Hospital, flow sheet maturation was an organic process, based on the evolving needs of teams, patients, and registries. Despite widespread use, scarcely are flow sheets mentioned in key publications of the time. Resources for optimal care of the injured patient make no reference nor provide any examples. Advanced trauma life support manuals reference the critical nature of recording events during resuscitation, but not until the eighth edition ${ }^{8}$ was a flow sheet mentioned and appended. Since then, the flow sheet has evolved into a multipage collection of many variables.

Given the origin, one would expect divergent forms. A review of a large number of trauma flow sheets reveals the organization of the data is scattered, and at a glance, dissimilar. However, 


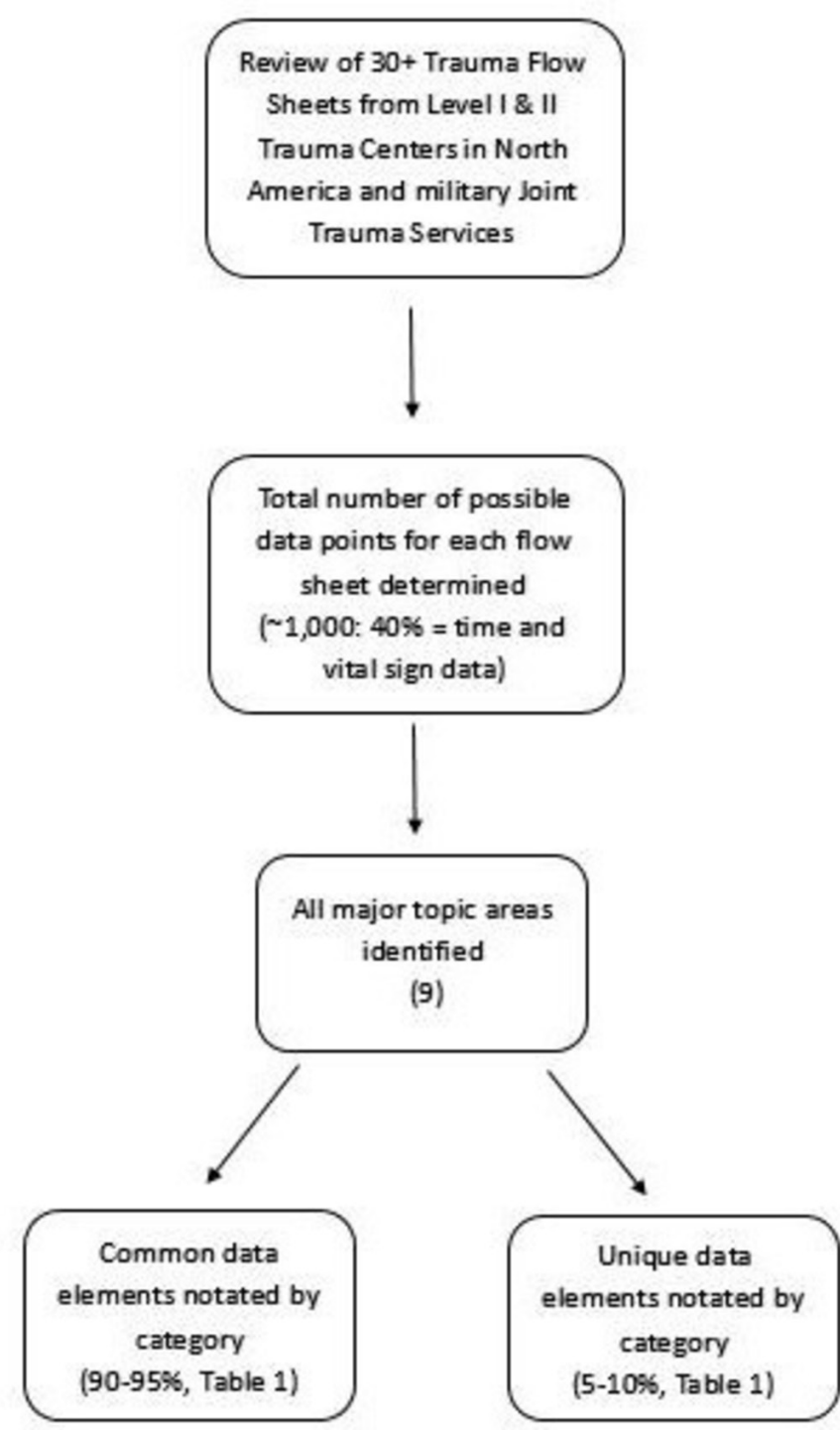

Figure 1 Iterative appraisal of flow sheet data points.

iterative appraisal of flow sheets with side-by-side comparisons for commonalities and unique attributes demonstrates near universal agreement on collected data (figure 1). This is a result of interactions at the national society level. Form sharing was rampant, and dissemination of information via the Society of Trauma Nurses (STN) and other societies resulted in a form with high congruency (E Whalen, personal communication, 2016). In essence, form followed function. Extensive literature search did not reveal any specific papers on flow sheet development, and a search of the archives at the American College of Surgeons failed to unearth any copies of flow sheets from inception to the current time, necessitating reliance on oral history.

A evaluation of a representative sample of flow sheets $(>30)$ from level I and II trauma centers across the USA, including the Armed Services, was undertaken. These were obtained directly from trauma centers or through an online search. All trauma flow sheets contained up to 1000 discrete data points. The large volume of information collected has resulted in multiple-paged flow sheets that vary in style and organization. Styles include four pages printed on two sides, to six-page trifold documents. All contain patient-related inputs and physiologic outputs, but vary with the addition of tables, diagrams, and commonly used guidelines. Variability is also evident in how data are collected: checklist versus pictures versus free text. Consistently, all flow sheets are organized into nine discrete areas of information but variably arranged. Beyond style and organization however, the content approaches $90 \%$ to $95 \%$ data congruence, a Darwinian phenomenon. Less than $5 \%$ to $10 \%$ of the data are unique and are either hospital-specific or needed in certain locations, such as combat zones (table 1). With neither a mandate nor consensus paper, the review reveals a universal set of categories. Each category contains essential data elements that allow expedient review of patient care and care processes. These nine categories are the following:

1. Prehospital information.

2. Trauma team response.

3. Medical history.

4. Patient assessment: primary and secondary surveys.

5. Procedural interventions.

6. Diagnostics.

7. Fluid, blood, and drugs.

8. Narrative and vital signs.

9. Disposition.

\section{PREHOSPITAL INFORMATION}

Most data are collected prior to patient arrival. Prehospital physiologic data direct appropriate triage and steer guideline improvements. ${ }^{9-12}$ "Readiness" and advance preparation are requirements of good trauma care. These are costly and accurate data critical to refine the essential resources for immediate patient care. ${ }^{13} 14$ The data confirm timely activation of specialized teams and the need, utilization, and cost of hospital support services (eg, radiology, operating room personnel). Data on demographics, mechanisms of injury, physiologic alterations, and field interventions provide valuable epidemiologic information and result in practice changes based on dogma to those based on evidence. This has fundamentally changed how prehospital care is delivered: alterations in prehospital intubation of patients with traumatic brain injury and methods to improve techniques and outcomes, ${ }^{15-17}$ confirmation that the stay-and-play mentality is dangerous, ${ }^{18}$ pneumatic antishock garment and tourniquet use, ${ }^{19-21}$ and changes in prehospital fluid delivery. ${ }^{22-24}$

\section{TRAUMA TEAM RESPONSE TIMES}

Timely team arrival is critical. Verification hinges on team availability and composition: full teams, partial teams, or even no team. The data support critical information needs: Was the team leader, critical for smooth resuscitation, present from the beginning? Was the correct complement of providers available? A wealth of studies regarding composition and team arrival times have been performed to validate and confirm the value of trauma teams. ${ }^{25-28}$ Provider response data enable determination of resource utilization and costs of initial trauma care.

\section{MEDICAL HISTORY}

Comorbid conditions such as coagulopathies, organ insufficiency, concurrent use of medications, and degenerative diseases directly impact patient care. Resuscitation and interventions are applied or altered based on this information. Physiologic data gathered during initial care allow the development of condition-specific algorithms to improve outcomes. Examples include rapid reversal of coagulopathy ${ }^{29-31}$ and the use of prehospital beta blockers to improve brain injury outcomes. ${ }^{32}$ 
Table 1 Common and unique data elements contained in trauma flow sheets by category

\begin{tabular}{|c|c|c|c|c|c|}
\hline \multicolumn{6}{|l|}{ Common Variables } \\
\hline $\begin{array}{l}\text { Prehospital }(\mathrm{PH}) \text { \& Team } \\
\text { Response }(1,2)\end{array}$ & $\begin{array}{l}\text { Medical History \& Patient } \\
\text { Assessment }(3,4)\end{array}$ & $\begin{array}{l}\text { Procedural } \\
\text { Interventions, } \\
\text { Diagnostics }(5,6)\end{array}$ & $\begin{array}{l}\text { Fluids Blood } \\
\text { Drugs (7) }\end{array}$ & $\begin{array}{l}\text { Narrativeand } \\
\text { Vital Signs (8) }\end{array}$ & Disposition (9) \\
\hline $\begin{array}{l}\text { Activation level } \\
\text { Upgrade/downgrade } \\
\text { Activation time } \\
\text { Transport mode } \\
\text { Agency } \\
\text { Team response and times } \\
\text { Mechanism of Injury } \\
\text { Safety devices } \\
\text { Cervical collar } \\
\text { Immobilization } \\
\text { Oxygen } \\
\text { PH arrest } \\
\text { LOC documented } \\
\text { Field vital signs } \\
\text { IV sites } \\
\text { Fluid infused - type } \\
\text { Fluid infused -amount } \\
\text { Medications } \\
\text { EtOH evident }\end{array}$ & $\begin{array}{l}\text { Arrival vitals } \\
\text { Primary survey } \\
\text { Adult GCS } \\
\text { Pediatric GCS } \\
\text { Secondary } \\
\text { Assessment } \\
\text { History } \\
\quad \text { Allergies } \\
\text { Medications } \\
\text { Pastlllness } \\
\text { Pregnancy } \\
\text { Lastmeal } \\
\text { Events } \\
\text { Height and weight } \\
\text { Injury diagram } \\
\text { Broselow Color }\end{array}$ & $\begin{array}{l}\text { Airway } \\
\text { Needle decompression } \\
\text { Chest tube } \\
\text { FAST } \\
\text { Pericardiocen tesis } \\
\text { Thoracotomy } \\
\text { Cross clamp time } \\
\text { Arterial line } \\
\text { IV access } \\
\text { Central access } \\
\text { Foley } \\
\text { Gastric tube } \\
\text { Peritoneal Lavage } \\
\text { Splints } \\
\text { REBOA } \\
\text { Cervical collar } \\
\text { CPR } \\
\text { Tourniquet } \\
\text { Spine board } \\
\text { Traction } \\
\text { Films:Cspine, Chest, Pelvis } \\
\text { CT:Head, Spine, Chest, Pelvis } \\
\text { Cystogram, IVP }\end{array}$ & $\begin{array}{l}\text { Crystalloids } \\
\text { Packed cells } \\
\text { Plasma } \\
\text { Platelets } \\
\text { Cryoprecipitate } \\
\text { Medications } \\
\text { Amount infused } \\
\text { Dose } \\
\text { Route } \\
\text { Time }\end{array}$ & $\begin{array}{l}\text { Time } \\
\text { Temperature } \\
\text { Blood pressure } \\
\text { Pulse } \\
\text { Respirations } \\
\text { End-tidal CO2 } \\
\text { 02saturations } \\
\text { Pupilsize (R/L) } \\
\text { GCS (EVM) } \\
\text { Pain 0-10 } \\
\text { Sedation1-7 } \\
\text { Written narrative }\end{array}$ & $\begin{array}{l}\text { Admit } \\
\text { Room number } \\
\text { Location } \\
\text { AMA } \\
\text { Transferred } \\
\text { Time out of ED } \\
\text { Report given } \\
\text { Died } \\
\text { Time } \\
\text { Coroner information } \\
\text { Organ donor services called } \\
\text { Valuables }\end{array}$ \\
\hline \multicolumn{6}{|l|}{ Unique Variables } \\
\hline $\begin{array}{l}\text { Prehospital(PH) \& Team } \\
\text { Response } \\
\text { (Military) } \\
(1,2)\end{array}$ & $\begin{array}{l}\text { MedicalHistory \& Patient } \\
\text { Assessment } \\
\text { (Civilian) } \\
(3,4)\end{array}$ & $\begin{array}{l}\text { Interventions\& Diagnostics } \\
\text { (Military) } \\
(5,6)\end{array}$ & $\begin{array}{l}\text { FluidsBlood Drugs } \\
\text { (7) }\end{array}$ & $\begin{array}{l}\text { Narrativeand Vital } \\
\text { Signs } \\
(8)\end{array}$ & $\begin{array}{l}\text { Disposition (Civilian/Military) } \\
\text { (9) }\end{array}$ \\
\hline $\begin{array}{l}\text { Evacuation site } \\
\text { Triage category } \\
\text { Armed services branch } \\
\text { PH warming devices }\end{array}$ & $\begin{array}{l}\text { Developmental delays } \\
\text { Pediatric feeding method } \\
\text { Social history } \\
\text { Infectious disease exposure } \\
\text { Advanced Directives } \\
\text { Learning needs } \\
\text { Chronic pain history }\end{array}$ & $\begin{array}{l}\text { Eye shield } \\
\text { Hemorrhage control measures } \\
\text { Wound Care } \\
\text { Level I use } \\
\text { Ventilator settings }\end{array}$ & & & $\begin{array}{l}\text { Hold- police, mental health } \\
\text { RTD } \\
\text { Evacuation to } \\
\text { Host Nation } \\
\text { Coalition } \\
\text { CASF } \\
\text { Evacuation mode }\end{array}$ \\
\hline
\end{tabular}

AMA, against medical advice; CPR, cardiopulmonary resuscitation; CT, Chest tube; ED, emergency department; EVM, eyes verbal motor; EtOH, alcohol; FAST, focused abdominal sonogram for trauma; GCS, Glasgow Coma Score; IV, intravenous; LOC, Loss of consciousness; PH, Prehospital; REBOA, resuscitative endovascular balloon of the aorta; RTD, return to duty.

\section{PATIENT ASSESSMENT: PRIMARY AND SECONDARY SURVEYS}

Resuscitation hinges on physical examination and physiologic response. Optimal resuscitation and orderly interventions are evidence-based. For civilians, the primary survey follows the ABCDE tenets of advanced trauma life support. ${ }^{8}$ In combat zones, exsanguination, rather than loss of airway, is the most immediate cause of death, resulting in reordering the primary survey with circulation as first priority. ${ }^{33}$ Validation of the Glasgow Coma Scale score provides clear guidelines for treatment and transfer. ${ }^{34} 35$ The utility, reliability, and safety of the elements of physical examination (prostate palpation, pelvic girdle manipulation) have been studied and amended. ${ }^{36-38}$ The survey, when done well, guides priorities and the provision of safe care.

\section{PROCEDURAL INTERVENTIONS}

Interventions are captured with times and impact on physiologic response. These can be evaluated for appropriateness, timeliness, and impact. Failure to consider interventions in the correct order or time frame can have dire consequences. ${ }^{39}$
Interventions can be assessed and judged for usefulness, deployment, and retention within the armamentarium of initial trauma care. Rapid sequence intubation continues to be refined $^{40}$ and anatomic positioning for needle decompression has been altered. ${ }^{41}$ The utility, timing, and usefulness of diagnostic peritoneal lavage, CT, ultrasound, pericardiocentesis, emergency thoracotomy, and balloon occlusion of the aorta continue to be evaluated. ${ }^{42-47}$ Many interventions, once globally popular, are now parsed into utility based on data-driven local and regional resources.

\section{DIAGNOSTICS}

Blood is drawn based on standing orders or specialty labs ordered as circumstances or patient condition warrants. At times, samples may not be collected quickly, are congealed, inadequate, or misplaced. Individualized orders can be missed during chaotic resuscitations. Thus, critical information is delayed. With appropriate documentation, this is evaluable and strategies to correct deficits possible. New and old tests can be evaluated for utility, such as thromboelastogram, pointof-care lactate, and lateral cervical spine plain films. Likewise, 
decision algorithms such as those for unstable pelvic fractures and treatment of great vessel injury are grounded in data from the trauma flow sheet. ${ }^{48-50}$

\section{FLUID, BLOOD, AND DRUGS}

Timing, amount, and types of resuscitative fluid are crucial to good outcomes. Aggressive crystalloids increase the risk of respiratory distress syndrome. Delays in blood product administration can cause organ dysfunction, and improper ratios promote coagulopathy, increased product use, and risk of death. Early blood product use algorithms are being continually refined. ${ }^{5152}$ Timing and dosages of medications are recorded and correlated with physiologic impact: hypotension during rapid sequence intubation, ${ }^{44}$ tranexamic acid to prevent further bleeding, and the role of etomidate in adrenal suppression. ${ }^{5354}$

\section{NARRATIVE AND VITAL SIGNS}

Every trauma has a story and every resuscitation should have a narrative. Narrative gives meaning to the data points, and when properly captured is rich in detailing successes and failures. Narrative provides insight into our Herculean resuscitative efforts. It adds meaning to the compilation of data points for a richer understanding of the interplay between patient physiology, response, and inputs melded into the sum total of team effort and patient outcome. Narrative lends insight into team leadership, clarifies reasons for points of departure from accepted guidelines, and allows a better understanding of unfolding events. Data give us the "what," narratives provide the "why." Without narratives, decisions and judgments would be made on incomplete data. ${ }^{55}{ }^{56}$ Narrative allows the studious reviewer a means to identify common areas of struggle that can serve as learning points or lend themselves to further study or automation to avoid future pitfalls. ${ }^{57}$

\section{DISPOSITION}

The course of resuscitation culminates here. How long did it take? Did they live? Was the operating room ready? Will a waiting patient get viable organs? Was throughput timely or delayed? Utilization of resources, costs, and impact on outcomes are obtained from this portion of the data set and essential to those in charge of conscientious, adequate, and appropriate use of resources. ${ }^{14} 15$

It is a credit to those that diligently developed and shared these data forms during the last 40 years. Thanks goes to the STN and the Committee on Trauma of the American College of Surgeons. Data congruence that approaches $95 \%$ is a testament to the functional value and validity of flow sheet. The same cannot be said about a form which remains highly variable. Given the critical nature of the information, data commonality, and unanimous use, the trauma flow sheet begs for a common form. Other than local politics, why hasn't this happened? Standardization would minimize charting variations, improve data collection, reduce errors of omission, enhance evaluation of care processes, simplify training, augment data collection for research across institutions, and improve patient safety.

This is an era of tremendous technologic advance. There are myriad innovative ways to collect, store, transmit, and use data. As a risk-averse profession mired in "too much to do with too little time," these technologic advances have not been fully realized, welcomed, or designed for our complex workflow and have added to the burden of our task without the realization of increased efficiencies, improved patient care, or safety. Dr Boyd stated that "as the profession becomes more knowledgeable of [the] ... ramifications of modern informational resources, more effective change will be possible." ${ }^{4}$ The time is ripe for the development of a unified minimum common data set and the migration to a real-time electronic data capture system.

The trauma flow sheet is an irreplaceable document that supports our quest for superlative trauma care: a data goldmine of initial processes of care, a critical aid to decision support, the backbone of appropriate triage, fundamental to our understanding of subtle and inconsistent physiologic responses, and vital to research endeavors. Informatics tools, such as the trauma flow sheet, support our translation of knowledge into practice and have changed the behavior of people, organizations, and systems. ${ }^{58}$ Future modifications and acceptance of a universal form that serves the needs of trauma teams, data registries, training, and scientific endeavors will ease the way to automation and ongoing growth of knowledge. In summary, no single entity can be credited with the development of the trauma flow sheet. It has been an organic evolution with input from a wide cohort of stakeholders-nurses, physicians, epidemiologists, and support of dedicated members of our national trauma societies. The value of the trauma flow sheet has gone unheralded and cannot be overstated, advancing trauma care in ways too numerous to count.

Acknowledgements The authors thank Eileen Whalen, MHA, RN, and Lori McDonald, MS, RN, TCRN, NE-BC, who agreed to be interviewed for this project.

Contributors JAD and TJS contributed to the literature search, writing, and critical revisions. MM contributed to critical revisions. KC assisted with the literature search and critical revisions.DRB is to be commended for his groundbreaking and visionary work on the development of our national trauma system. Additionally, he provided invaluable historical context to assist with completion of the manuscript.

Funding The authors have not declared a specific grant for this research from any funding agency in the public, commercial or not-for-profit sectors.

Competing interests None declared.

Patient consent Not required.

Provenance and peer review Not commissioned; externally peer reviewed.

Open access This is an open access article distributed in accordance with the Creative Commons Attribution Non Commercial (CC BY-NC 4.0) license, which permits others to distribute, remix, adapt, build upon this work non-commercially, and license their derivative works on different terms, provided the original work is properly cited, appropriate credit is given, any changes made indicated, and the use is non-commercial. See: http://creativecommons.org/licenses/by-nc/4.0/

\section{REFERENCES}

1. Nightingale F. Notes on Hospitals. Enlarged and for the most part rewritten. 3rd edn. London: Longman, Green, Longman, Roberts, and Green, 1863.

2. Werley HH, Lang NM. Preface. Identification of the nursing minimum data set. New York, NY: Springer, 1987

3. National Academy of Sciences-National Research Council (NAS-NRC). Accidental death and disability: the neglected disease of modern society. Division of Medical Sciences, Washington: NAS-NRC, 1966.

4. Boyd DR, Lowe RJ, Baker RJ, Nyhus LM, Registry T. Trauma registry. new computer method for multifactorial evaluation of a major health problem. JAMA 1973;223:422-9.

5. Boyd DR. A trauma surgeon's journey. J Trauma Acute Care Surg 2015;79:497-514.

6. Boyd DR, Rappaport DM, Marbarger JP, Baker RJ, Nyhus LM. Computerized trauma registry: a new method for categorizing physical injuries. Aerosp Med 1971:42:607-15.

7. American College of Surgeons. Hospital and prehospital resources for optimal care of the injured patient. Chicago, IL, 1987.

8. American College of Surgeons. Advanced trauma life support. Chicago, IL, 1978.

9. Morris JA, Auerbach PS, Marshall GA, Bluth RF, Johnson LG, Trunkey DD. The Trauma Score as a triage tool in the prehospital setting. JAMA 1986;256:1319-25.

10. Esposito TJ, Offner PF, Jurkovich GJ, Griffith J, Maier RV. Do prehospital trauma center triage criteria identify major trauma victims? Arch Surg 1995;130:171-6.

11. Haas B, Gomez D, Zagorski B, Stukel TA, Rubenfeld GD, Nathens AB. Survival of the fittest: the hidden cost of undertriage of major trauma. J Am Coll Surg 2010;211:804-11. 
12. Claridge JA, Golob JF, Leukhardt WH, Kan JA, Como JJ, Malangoni MA, Yowler CJ. Trauma team activation can be tailored by prehospital criteria. Am Surg 2010;76:1401-7.

13. Taheri PA, Butz DA, Lottenberg L, Clawson A, Flint LM. The cost of trauma center readiness. Am J Surg 2004;187:7-13.

14. Davis JS, Graygo J, Augenstein J, Schulman Cl. Prehospital information for optimal patient care. Am Surg 2013;79:441-3.

15. Fakhry SM, Scanlon JM, Robinson L, Askari R, Watenpaugh RL, Fata P, Hauda WE, Trask A. Prehospital rapid sequence intubation for head trauma: conditions for a successful program. J Trauma 2006;60:997-1001.

16. Davis DP, Peay J, Sise MJ, Vilke GM, Kennedy F, Eastman AB, Velky T, Hoyt DB. The impact of prehospital endotracheal intubation on outcome in moderate to severe traumatic brain injury. J Trauma 2005;58:933-9.

17. Murray JA, Demetriades D, Berne TV, Stratton SJ, Cryer HG, Bongard F, Fleming A, Gaspard D. Prehospital intubation in patients with severe head injury. J Trauma 2010;69:595-9.

18. Ivatury RR, Nallathambi MN, Roberge RJ, Rohman M, Stahl W. Penetrating thoracic injuries: in-field stabilization vs. prompt transport. J Trauma 1987;27:1066-73.

19. McSwain NE. Pneumatic anti-shock garment: state of the art 1988. Ann Emerg Med 1988; 17:506-25.

20. Lateef $F$, Kelvin T. Military anti-shock garment: historical relic or a device with unrealized potential? J Emerg Trauma Shock 2008;1:63-9.

21. Passos E, Dingley B, Smith A, Engels PT, Ball CG, Faidi S, Nathens A, Tien H, Canadian Trauma Trials Collaborative. Tourniquet use for peripheral vascular injuries in the civilian setting. Injury 2014;45:573-7.

22. Cotton BA, Jerome R, Collier BR, Khetarpal S, Holevar M, Tucker B, Kurek S, Mowery NT, Shah K, Bromberg W, et al. Guidelines for prehospital fluid resuscitation in the injured patient. J Trauma 2009:67:389-402.

23. Haut ER, Kalish BT, Cotton BA, Efron DT, Haider AH, Stevens KA, Kieninger AN, Cornwell EE, Chang DC. Prehospital intravenous fluid administration is associated with higher mortality in trauma patients: a National Trauma Data Bank analysis. Ann Surg 2011;253:371-7.

24. Cooper DJ, Myles PS, McDermott FT, Murray LJ, Laidlaw J, Cooper G, Tremayne AB, Bernard SS, Ponsford J. Prehospital hypertonic saline resuscitation of patients with Hypotension and severe traumatic brain injury: a randomized controlled trial. Ann Emerg Med 1988;17:506-25.

25. Driscoll PA, Vincent CA. Variation in trauma resuscitation and its effect on patient outcome. Injury 1992;23:111-5.

26. Lucas CE, Dombi GW, Crilly RJ, Ledgerwood AM, Yu P, Vlahos A. Neurosurgical trauma call: use of a mathematical simulation program to define manpower needs. J Trauma 1997;42:818-24.

27. Luchette F, Kelly B, Davis K, Johanningman J, Heink N, James L, Ottaway M, Hurst J. Impact of the in-house trauma surgeon on initial patient care, outcome, and cost. $J$ Trauma 1997:42:490-7.

28. Porter JM, Ursic C. Trauma attending in the resuscitation room: does it affect outcome? Am Surg 2001;67:611-4.

29. Coimbra R, Hoyt DB, Anjaria DJ, Potenza BM, Fortlage D, Hollingsworth-Fridlund P. Reversal of anticoagulation in trauma: a North-American survey on clinical practices among trauma surgeons. J Trauma 2005;59:375-82.

30. Ilyas C, Beyer GM, Dutton RP, Scalea TM, Hess JR. Recombinant factor VIla for warfarin-associated intracranial bleeding. J Clin Anesth 2008;20:276-9.

31. Berndtson AE, Coimbra R. The epidemic of pre-injury oral antiplatelet and anticoagulant use. Eur J Trauma Emerg Surg 2014;40:657-69.

32. Mohseni $S$, Talving $P$, Wallin $G$, Ljungqvist $O$, Riddez L. Preinjury $\beta$-blockade is protective in isolated severe traumatic brain injury. J Trauma Acute Care Surg 2014;76:804-8

33. US Department of Defense. Tactical combat casualty care and wound treatment. New York, NY: Skyhorse Publishing, 2016.

34. Jennett B, Teasdale G, Braakman R, Minderhoud J, Knill-Jones R. Predicting outcome in individual patients after severe head injury. The Lancet 1976;307:1031-4.

35. Teasdale G, Maas A, Lecky F, Manley G, Stocchetti N, Murray G. The glasgow coma scale at 40 years: standing the test of time. Lancet Neurol 2014;13:844-54.

36. Esposito TJ, Ingraham A, Luchette FA, Sears BW, Santaniello JM, Davis KA, Poulakidas SJ, Gamelli RL. Reasons to omit digital rectal exam in trauma patients: no fingers, no rectum, no useful additional information. J Trauma 2005;59:1314-9.
37. Ball CG, Jafri SM, Kirkpatrick AW, Rajani RR, Rozycki GS, Feliciano DV, Wyrzykowski $A D$. Traumatic urethral injuries: does the digital rectal examination really help us? Injury 2009;40:984-6.

38. Sauerland S, Bouillon B, Rixen D, Raum MR, Koy T, Neugebauer EAM. The reliability of clinical examination in detecting pelvic fractures in blunt trauma patients: a metaanalysis. Arch Orthop Trauma Surg 2004;124:123-8.

39. Clarke JR, Spejewski B, Gertner AS, Webber BL, Hayward CZ, Santora TA, Wagner DK, Baker CC, Champion HR, Fabian TC, et al. An objective analysis of process errors in trauma resuscitations. Academic Emergency Medicine 2000;7:1303-10.

40. Upchurch CP, Grijalva CG, Russ S, Collins SP, Semler MW, Rice TW, Liu D, Ehrenfeld JM, High K, Barrett TW, et al. Comparison of etomidate and ketamine for induction during rapid sequence intubation of adult trauma patients. Ann Emerg Med 2017;69:24-33.

41. McSwain NE. The McSwain Dart: device for relief of tension pneumothorax. Med Instrum 1982;16:249-50.

42. Root HD, Hauser CW, McKinley CR, Lafave JW, Mendiola RP. Diagnostic peritoneal lavage. Surgery 1965;57:633-7.

43. Frame SB, Browder IW, Lang EK, McSwain NE. Computed tomography versus diagnostic peritoneal lavage: usefulness in immediate diagnosis of blunt abdominal trauma. Ann Emerg Med 1989;18:513-6.

44. Rozycki GS, Ballard RB, Feliciano DV, Schmidt JA, Pennington SD. Surgeon-performed ultrasound for the assessment of truncal injuries: lessons learned from 1540 patients. Ann Surg 1998;228:557-67.

45. Lee TH, Ouellet JF, Cook M, Schreiber MA, Kortbeek JB. Pericardiocentesis in trauma: a systematic review. J Trauma Acute Care Surg 2013;75:543-9.

46. American College of Surgeons. Chapter 4 thoracic trauma advanced trauma life support. 10th edn. Chicago, IL, 1978.

47. DuBose JJ, Scalea TM, Brenner M, Skiada D, Inaba K, Cannon J, Moore L, Holcomb J, Turay D, Arbabi CN, et al. The AAST prospective aortic occlusion for resuscitation in trauma and acute care surgery (AORTA) registry: data on contemporary utilization and outcomes of aortic occlusion and resuscitative balloon occlusion of the aorta (REBOA). J Trauma Acute Care Surg 2016;81:409-19.

48. Fabian TC, Davis KA, Gavant ML, Croce MA, Melton SM, Patton JH, Haan CK, Weiman DS, Pate JW. Prospective study of blunt aortic injury: helical CT is diagnostic and antihypertensive therapy reduces rupture. Ann Surg 1998;227:666-76.

49. Croce MA, Magnotti LJ, Savage SA, Wood GW, Fabian TC. Emergent pelvic fixation in patients with exsanguinating pelvic fractures. J Am Coll Surg 2007;204:935-9.

50. Burlew CC, Moore EE, Smith WR, Johnson JL, Biffl WL, Barnett CC, Stahel PF. Preperitoneal pelvic packing/external fixation with secondary angioembolization: optimal care for life-threatening hemorrhage from unstable pelvic fractures. J Am Coll Surg 2011;212:628-35.

51. Stein DM, Dutton RP, Kramer ME, Scalea TM. Reversal of coagulopathy in critically ill patients with traumatic brain injury: recombinant factor VIla is more cost-effective than plasma. J Trauma 2009;66:63-75.

52. Holcomb JB, Tilley BC, Baraniuk S, Fox EE, Wade CE, Podbielski JM, del Junco DJ, Brasel KJ, Bulger EM, Callcut RA, et al. Transfusion of plasma, platelets, and red blood cells in a 1:1:1 vs a 1:1:2 ratio and mortality in patients with severe trauma: the PROPPR randomized clinical trial. JAMA 2015:313:471-82.

53. Pusateri AE, Weiskopf RB, Bebarta V, Butler F, Cestero RF, Chaudry IH, Deal V, Dorlac WC, Gerhardt RT, Given MB, et al. Tranexamic acid and trauma: current status and knowledge gaps with recommended research priorities. Shock 2013;39:121-6.

54. Hildreth AN, Mejia VA, Maxwell RA, Smith PW, Dart BW, Barker DE. Adrenal suppression following a single dose of etomidate for rapid sequence induction: a prospective randomized study. J Trauma 2008;65:573-9.

55. Hjortdahl M, Ringen AH, Naess A-C, Wisborg T. Leadership is the essential nontechnical skill in the trauma team - results of a qualitative study. Scand J Trauma Resusc Emerg Med 2009;17:48.

56. Wilson KA, Salas E, Priest HA, Andrews D. Errors in the heat of battle: taking a closer look at shared cognition breakdowns through teamwork. Hum Factors 2007:49:243-56

57. Parimi N, Hu PF, Mackenzie CF, Yang S, Bartlett ST, Scalea TM, Stein DM. Automated continuous vital signs predict use of uncrossed matched blood and massive transfusion following trauma. J Trauma Acute Care Surg 2016;80:897-906.

58. Ozbolt JG, Saba VK. A brief history of nursing informatics in the United States of America. Nurs Outlook 2008;56:199-205. 